Paulina Bździuch *, Marek Bogacki *

\title{
Evaluating the influence of modernization of the urban bus fleet in Krakow in the years 2010-2015 on the amount of pollutants emitted into the air ${ }^{1}$
}

\author{
Ocena wpływu modernizacji floty autobusów miejskich \\ w Krakowie w latach 2010-2015 na ilość emitowanych \\ do powietrza zanieczyszczeń
}

\begin{abstract}
* mgr inż. Paulina Bździuch, dr inż. Marek Bogacki - AGH University of Science and Technology, Faculty of Mining Surveying and Environmental Engineering, Department of Environmental Management and Protection, al. Mickiewicza 30, 30-059 Krakow, e-mail: bzdziuch@agh.edu.pl, bogacki@agh.edu.pl
\end{abstract}

Keywords: air pollutant, emission, urban bus public transport, COPERT 4

Słowa kluczowe: zanieczyszczenie powietrza, emisja, transport publiczny, autobusy, COPERT 4

\begin{abstract}
Efficient and environmentally friendly public transport is a requirement of a modern city. For many years, Krakow has been building a modern multimodal transportation system, with the bus services playing a significant role. The article presents the results of the studies carried out on the fleet of urban buses operating within the Krakow agglomeration in the years 20102015. The influence of modernization of the urban bus fleet in the specified period on emissions of the most significant air pollutants into the air was evaluated. The studies have confirmed a total reduction in emissions from buses during the study period at levels of approximately $28 \%$ for NOx, approximately $35 \%$ for PM10, approximately $39 \%$ for PM2.5 and approximately $43 \%$ for NMVOC.
\end{abstract}

(C) IOŚ-PIB

\section{INTRODUCTION}

Efficient public transport in large metropolitan areas facilitates the mobility of passengers and goods, thus improving the quality of life [Ahanchian et al. 2014]. However, it may have an adverse effect on the environment, especially by affecting the air quality [Martínez-Jaramillo et al. 2017]. The results of research studies carried out worldwide demonstrate that means of transport are one of the largest sources of dust-gas emissions into the air, including the greenhouse gases (e.g., $\mathrm{CO}_{2}$ ) [Dulal et al. 2011; Grazi et al. 2008]. More and more frequently, the travellers expect public transport to be not only well organized, but also eco-friendly. Therefore, a need to limit the influence of public transport on the environment, especially on air quality, is a major challenge for urban areas which are subjected to enormous human pressure due to the recently increased car traffic [Kumar Pathak et al. 2016; Moreno et al. 2015; Nanaki et al. 2017].

${ }^{1}$ This study was supported by the AGH University of Science and Technology statutory research No.11.11.150.008 (Faculty of Mining Surveying and Environmental Engineering)

\section{Streszczenie}

Sprawny i ekologiczny transport publiczny jest wymogiem współczesnego miasta. Kraków od wielu lat buduje nowoczesny multimodalny system transportowy, w którym znaczącą rolę odkrywa transport autobusowy. W artykule przedstawiono wyniki badań przeprowadzonych na flocie autobusów miejskich, poruszających się na terenie aglomeracji krakowskiej w latach 2010-2015. Oceniono wpływ modernizacji taboru autobusów w badanym okresie na wielkości emisji do powietrza najistotniejszych zanieczyszczeń komunikacyjnych. Badania potwierdziły sumaryczną redukcję wielkości emisji z autobusów w latach 2010-2015 na poziomie: ok. $28 \%$ - NOx, ok. $35 \%$ - PM10, ok. $39 \%$ - PM2.5 ok. $43 \%$ - NMVOC.
The metropolitan area of Krakow, with a population of over 750 thousand permanent residents and approximately 250 thousand temporary residents, is characterized by dense development, especially in its central part, and a well-developed road network with heavy local traffic and partly transit traffic as well. It is located in the ancient valley of Vistula River, surrounded by hills. Such a location determines the unfavourable anemographic conditions prevailing in Krakow, which significantly affects the air quality in the city. In 2016, the air pollution monitoring station in Krakow (Krasinski Avenue) noted 165 days of above-average daily concentrations of fine particulate matter and the exceeded limit values of the annual average concentration of nitrogen dioxide by $50 \%$ [WIOŚ 2017]. In this context, carrying out activities aimed at reducing the emissions of pollutants into the air from public transport in Krakow is of particular importance.

The article demonstrates the results of research studies performed on the fleet of urban buses operating within the Krakow agglomeration in the years 2010-2015, in order to assess the 
level of their emissions into the air. The studies were conducted using the computer program COPERT 4, created at the Aristotle University of Thessaloniki in Greece, based on the CORINAIR methodology developed by the European Environment Agency (EEA) [Gkatzofilias et al. 2012; Hausberger et al. 2009; Kouridis et al. 2013; Rexeis et al. 2013].

\section{THE SYSTEM OF KRAKOW PUBLIC TRANSPORT}

The city of Krakow, with its compact development and a dense network of roads, requires effective transport policy, including policy on public transport. This policy should be aimed at continuous replacement of old fleet of buses with the ecological vehicles equipped with internal combustion engine/hybrid engine that meet the highest emission standards expressed in Euro standards [European Parliament and Council of the European Union 2009] or equipped with electric motor (zero-emission buses).

In the first quarter of 2016, as per the data provided by the Central Register of Vehicles and Drivers (CEPiK), there were more than 531,000 vehicles in Krakow, mainly passenger cars (80.6\%) and trucks $(12.1 \%)$, which played a key role in urban traffic . Among those vehicles that belong to the Krakow residents, only $7.8 \%$ meet the requirements of the latest applicable Euro $\mathrm{VI}$ emission standard, over $26 \%$ of the whole fleet constitute the vehicles older than 24 years, which do not meet the Euro emission standards. The remaining vehicles meet the emission standards of Euro I to Euro V. In addition to the vehicles belonging to the Krakow residents, there are also other vehicles arriving from outside Krakow and it is impossible to assess the technical condition of these vehicles.

The Municipal Infrastructure and Transport Management (ZIKiT) in Krakow has been responsible for the organization and functioning of Krakow's public transport since 2006. The passenger transportation services in Krakow is provided by two carriers - Municipal Transport Company S.A. in Krakow (MPK S.A.) and Mobilis group Sp. z o. o. Krakow. As of 1 October 2016, MPK S.A. in Krakow had 395 trams, 530 motor buses and 10 electric buses ( 5 leased and 5 of their own) at their disposal [MPK S.A. 2016]. Mobilis group Sp. z o. o. is the first private carrier in Krakow, commissioned by ZIKiT. In 2008, Mobilis company signed a 7-year contract to use 29 buses serving four bus lines. With a new contract signed in 2014 for another 10 years, it assumed the operation of 67 eco-buses, which are meant for regularly serving the passengers on 12 urban lines [Mobilis group Sp. z o.o. 2016]. According to the information provided by ZIKiT, at the end of 2015, the length of the daily routes of tram lines was close to 102 $\mathrm{km}$, while the daily bus lines covered more than 1,000 kilometres. ZIKiT estimates that each day, the public transport vehicles carry out about 1.2 million journeys ( 0.5 million passengers), and their number is constantly increasing. The modern fleet and more frequent services of buses and trams contribute to the increasing interest of the residents in using public transport. This trend has been noted in the statistics regarding ticket purchase. Thanks to the numerous nationwide innovative solutions, the organization of public transport system in Krakow is one of the best in Poland, and the city has become one of the pioneers in the field of testing spatial solutions friendly to users and the implementation of projects aimed at privileged tram and bus communication.

\section{RESEARCH METHODOLOGY}

In order to carry out research studies related to the estimation of the dust-gas emissions into the air from urban buses in the Krakow metropolitan area, CORINAIR methodology was used, developed as a part of the CORINE program of the European Environment Agency (EEA). The latest update of the CORINAIR methodology is of 2016 [EMEP/EEA 2016], however, the analyses performed in this study were carried out based on the 2013 version [EMEP/EEA 2013].

CORINAIR methodology divides the road traffic emissions into three types - emissions from fuel combustion, emissions from gasoline evaporation from the vehicle, and the emissions from wear and tear of tires, brakes and road surface abrasion. It contains a description of the methodology, emission factors and relevant data needed to calculate the emissions for following categories of road vehicles: passenger cars, light commercial vehicles - LCVs (<3.5 Mg), heavy duty vehicles - HDVs (> $3.5 \mathrm{Mg}$ ), coaches and urban buses, as well as mopeds and motorcycles. The methodology for estimating the dust-gas emissions from urban buses was used as part of the research. The most important pollutants emitted by buses and other road vehicles, where emissions can be estimated using the factors of the CORINAIR methodology include, among others, ozone precursors $\left(\mathrm{NO}_{x}\right.$, NMVOC, CO), greenhouse gases $\left(\mathrm{CO}_{2}, \mathrm{CH}_{4}, \mathrm{~N}_{2} \mathrm{O}\right)$, acidifying agents $\left(\mathrm{SO}_{2}\right), \mathrm{NH}_{3}$, particulate matter (PM), persistent organic pollutants (POPs), carcinogens (including polycyclic aromatic hydrocarbons, PAHs), toxic substances (dioxins and furans) and heavy metals [Kouridis et al. 2013].

The emission factors, derived under the CORINAIR program, were implemented in the computer program COPERT 4, which allowed for the calculation of emissions from the aforementioned categories of vehicles [Gkatzofilias et al. 2012]. The standard information content supplying the COPERT 4 calculation model for the emissions included:

- average values of the meteorological parameters for the calculation period (minimum and maximum temperatures and humidity, the value of partial pressure of fuel vapours in the tank of the vehicle),

data on the type of fuel and its consumption during the calculation period,

qualitative structure of the analysed vehicle fleet,

traffic data (number of vehicles in a specific category and the average number of kilometres travelled by one vehicle of a specific type in the calculation period),

data relating to the average speeds of the analysed vehicles, and the percentage share of the analysed vehicles' mileage in urban traffic, extra-urban traffic and on highways [Hausberger et al. 2009].

The total of a vehicle is calculated as the sum of three emissions: cold, hot and emission from evaporation. For each of them, the factors are calculated separately. In the study conducted on the 
fleet of urban buses in Krakow, the total emission was expressed only as the hot emission. For this category of road vehicles, the cold emission (emission up to a point when appropriate thermal parameters of the engine are reached) is not calculated because the methodology assumes that a bus that is leaving already has a warmed-up engine. Accordingly, in this case, it is not required to enter the meteorological data for the calculation period. Moreover, the emission from evaporation, which takes into account the evaporation of gasoline, is also omitted due to the fact that the analysed fleet of buses is equipped with combustion engines powered by diesel fuel with a very low coefficient of volatility [Gkatzofilias et al. 2012].

The input data for the calculations of emissions were provided by the carriers, namely: MPK S.A. and Mobilis group Sp. z o. o.

\section{EVALUATING THE CHANGES IN POLLUTANTS EMITTED INTO THE AIR FROM THE KRAKOW URBAN BUS FLEET IN THE YEARS 2010-2015}

The performed studies aimed to evaluate the influence of modernization of the urban bus fleet in Krakow on the reduction of dust-gas emissions into the air in the Krakow agglomeration.

The prevailing number of public transport bus lines and the vehicles operating in the Krakow agglomeration belong to MPK S.A. Before 2014, it was $94 \%$ of the entire fleet of buses serving the Krakow public bus transport. Since 2008, as a result of the demonopolization of the market of transportation services, the buses of the company Mobilis group Sp. z o. o. also operate on the Krakow roads. With the signing of a new contract in 2015 , their share rose to nearly $12 \%$.

Table 1 summarizes the state of the Krakow bus fleet in the years 2010-2015, regarding the types of buses (midi, standard and articulated) and meeting the emission standards.

In the years 2008-2014, the company Mobilis was operating 29 vehicles, serving four bus lines (nearly 2.5 million kilometres annually), whose engines met the Euro IV emission standard, applicable since 2006. Since 2015, the company Mobilis provides the transportation services on 12 urban lines and one extra line operating only during the holiday season. It has a total of 67 eco-friendly buses that meet the Euro VI emission standard. It is expected that annually, they will cover a total distance of more than 5 million kilometres.

In 2010, MPK S.A. had a total of 514 vehicles (including one restored vehicle, classified as a historical vehicle) and covered nearly 38 million kilometres each year around the Krakow agglomeration.

In order to analyse the modernization trends of the MPK S.A. bus fleet over the years 2010-2015, its status in 2010 was analysed and then compared to its state in 2015 . The percentage share of the buses meeting the relevant emission standards in the year 2010 and 2015 are illustrated in Figures 1a and 1b.

As demonstrated in Figure 1a, the largest group of vehicles operating on Krakow's roads constituted the buses which met the Euro III emission standard, in force since 2000 (approx. 34 $\%$ ), most of which were the articulated buses (almost $43 \%$ of the vehicles were with engines that met the Euro III emission
Table 1. Comparison of the number of buses operating in the Krakow agglomeration in the years 2010-2015, taking into account the types of buses and meeting the emission standards (data used in the calculations).

\begin{tabular}{|c|c|c|c|c|c|c|c|}
\hline \multicolumn{2}{|c|}{ Bus fleet } & \multicolumn{6}{|c|}{$\begin{array}{c}\text { Number of buses operated by MPK } \\
\& \text { Mobilis (pcs) }\end{array}$} \\
\hline Type & $\begin{array}{l}\text { Legislation } \\
\text { Standard }\end{array}$ & 2010 & 2011 & 2012 & 2013 & 2014 & 2015 \\
\hline \multirow{5}{*}{ 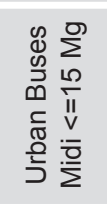 } & Conventional & 1 & 2 & 6 & 6 & 5 & 5 \\
\hline & Euro III & 50 & 50 & 50 & 50 & 47 & 47 \\
\hline & Euro IV & 5 & 5 & 5 & 5 & 5 & 5 \\
\hline & Euro V & 7 & 8 & 8 & 8 & 8 & 8 \\
\hline & Euro VI & - & - & - & - & - & 5 \\
\hline \multirow{6}{*}{ 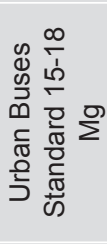 } & Euro I & 46 & 45 & 34 & 19 & 2 & 2 \\
\hline & Euro II & 109 & 98 & 83 & 80 & 64 & 63 \\
\hline & Euro III & 50 & 50 & 50 & 50 & 50 & 50 \\
\hline & Euro IV & 19 & 19 & 19 & 19 & 19 & - \\
\hline & Euro $\mathrm{V}$ & 53 & 61 & 81 & 106 & 106 & 106 \\
\hline & Euro VI & - & - & - & - & 28 & 53 \\
\hline \multirow{7}{*}{ 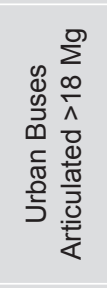 } & Conventional & 1 & 1 & 1 & 1 & - & - \\
\hline & Euro I & 27 & 13 & 7 & 3 & 2 & 1 \\
\hline & Euro II & 58 & 52 & 46 & 45 & 35 & 35 \\
\hline & Euro III & 75 & 75 & 75 & 75 & 75 & 75 \\
\hline & Euro IV & 10 & 10 & 10 & 10 & 10 & - \\
\hline & Euro $\mathrm{V}$ & 27 & 49 & 59 & 63 & 64 & 64 \\
\hline & Euro VI & - & - & - & - & 9 & 47 \\
\hline $\begin{array}{l}\text { Urban } \\
\text { CNG } \\
\text { Buses }\end{array}$ & EEV & 5 & 5 & 5 & 5 & 5 & 5 \\
\hline Electric & Zero-emissions & - & - & - & - & 6 & 5 \\
\hline & Total & 543 & 543 & 539 & 545 & 540 & 576 \\
\hline
\end{tabular}

standard). The remaining share had the standard buses and midi buses in equal parts. The second, almost equinumerous group of the vehicles were the buses with the Euro II engines (the standard entered into force in 1996), representing nearly $32.5 \%$ of the total fleet, the vast majority of which were the standard buses (approx. $65 \%$ of all the vehicles in use with the Euro II engine). Over $14 \%$ of the fleet constituted vehicles with Euro I engines, nearly $12.5 \%$ are the vehicles with the Euro $V$ engine, and about $4.5 \%$ - the vehicles that meet the EEV requirements. Meeting the requirements of EEV was voluntary for the vehicle owners and the emission standards applicable to EEV fell between the requirements of Euro $V$ and Euro VI. In the emission calculations, the buses with EEV engines were classified as vehicles meeting the Euro $V$ emission standard (the CORINAIR methodology does not provide for the emission factor for EEV engines installed in urban buses). Majority of vehicles with Euro IV engines on the Krakow roads (Table 1) were owned by the company Mobilis group. In the fleet of MPK S.A., they accounted for less than $2 \%$, half of which were the midi vehicles, and rest were the vehicles powered by natural gas CNG. Due to lack in the CORINAIR methodology of emission factor for the calculation of emissions from the buses powered by natural gas CNG, meeting the Euro IV emission standard - in the calculations, the buses of MPK S.A. were classified as meeting the EEV standard. Taking into account the emission standards applicable in 2010, it can be stated that 

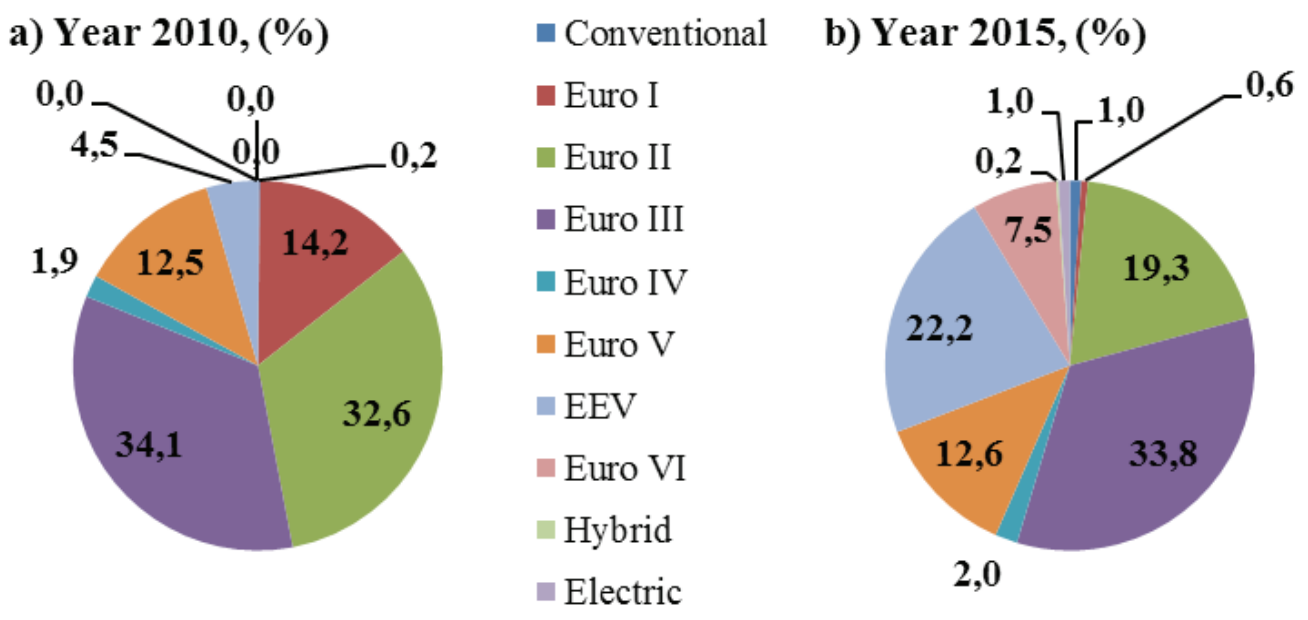

- Conventional

- Euro I

Euro II

- Euro III

Euro IV

Euro V

EEV

Euro VI

Hybrid

Electric

Figure 1. Percentage of the MPK S.A. buses in 2010 (a) and 2015 (b), meeting the relevant emission standards.

the fleet of MPK S.A. was relatively old (Euro I - Euro IV) and little ecological (almost $83 \%$ of the vehicles failed to meet the binding Euro $V$ emission standards).

Over the years 2010-2015, MPK S.A. carried out a series of modernization works of its bus fleet. It gradually withdrew the vehicles meeting the oldest emission standards (Euro I and Euro II), while replacing them with those with the EEV and Euro VI engines, and also tested other more environmentally friendly solutions, such as electric and hybrid buses. In 2015, the fleet of MPK S.A. consisted of 509 vehicles, which covered a total of over 35 million kilometres, of which 5 vehicles were historic buses (approx. 7,000 km annually), and another 5 vehicles were zero-emission electric buses serving one communication line (approx. 110,000 km per year). As it is illustrated in Figure 1b, the buses with engines meeting the Euro I emission standard accounted for only $0.6 \%$ of the entire fleet (this share decreased by more than $13 \%$ as compared to 2010 ), and $19.3 \%$ with Euro II engines (decreased by approx. $13 \%$ as compared to 2010). The vehicles with Euro III engines still constituted the largest group (approx. $33.8 \%$ of the total fleet), and the second place belonged to vehicles with EEV engines (over $22 \%$ of the total fleet). The buses with Euro IV and Euro V engines still accounted for $2 \%$ and $12.5 \%$ of the fleet, respectively (in the same proportions since 2010). On the other hand, the fleet of Krakow carrier was enhanced by a group of buses with the Euro VI engines, accounting for approximately $7.5 \%$.

To sum it up, 142 vehicles with the worst emission standards (mainly Euro I and II) were decommissioned; in their place, 129 new vehicles were purchased (91 EEV, 38 Euro VI), and 5 electric buses were tested, for which special charging stations were built.

Figures $2 \mathrm{a}$ and $2 \mathrm{~b}$ demonstrate the percentage variability of emissions of dust-gas pollutants into the air from the urban buses in Krakow in the years 2010-2015. In 2010, the bus fleet of MPK S.A. emitted a total of over $440 \mathrm{Mg}$ of nitrogen oxides $\left(\mathrm{NO}_{x}\right)$ (with over $87 \%$ emitted by the oldest fleet), almost $12 \mathrm{Mg}$ of PM10 (include $2.8 \mathrm{Mg}$ from the abrasion of tires and brakes) and almost $10.5 \mathrm{Mg}$ of PM2.5 (include 1.4 Mg from the abrasion of tires and brakes), and over $9 \mathrm{Mg}$ PM from fuel combustion (with nearly $92 \%$ emitted by the oldest fleet), and more than $34 \mathrm{~g}$ of benzo(a)pyrene (with $75 \%$ by the oldest vehicles). On the other hand, for the year 2015, these values were as follows: emissions of nitrogen oxides $\left(\mathrm{NO}_{x}\right)$ - about $327 \mathrm{Mg}$, over $63 \%$ of which was the emission of the obsolete fleet (Euro I - Euro IV), PM10 emission - about 7.6 Mg and PM2.5 emission - about $6.3 \mathrm{Mg}$ (include $2.5 \mathrm{Mg}$ of PM10 and $1.2 \mathrm{Mg}$ of PM2.5 from tire and brake abrasion), and $5.1 \mathrm{Mg}$ from fuel combustion (with almost $70 \%$ emissions by the oldest vehicles) and the emission of benzo(a)pyrene - about $31.5 \mathrm{~g}$ (with almost $50 \%$ emissions by the oldest vehicles). As it can be seen in Figure 2a, over the years 2010-2015, there was a reduction in the emissions of nitrogen oxides by nearly $26 \%$, of PM10 by more than $36 \%$, and of benzo(a)pyrene by more than $7 \%$. Such a small decrease in the emissions of the last contaminant may result from the lack of legislation imposing some limitations in this respect. In case of the other two pollutants, the reduction can be noticed as well (as illustrated in Figure $2 \mathrm{a}$ ) - by nearly $40 \%$ for PM2.5 and by over $43 \%$ for NMVOCs.

The bus fleet of Mobilis, serving the passengers in the years 2008-2014, annually emitted over $19 \mathrm{Mg}$ of nitrogen oxides ( $\mathrm{NO}_{x}$, the main pollutant in transportation), $0.34 \mathrm{Mg}$ of PM10 (about $55 \%$ from the abrasion of tire and brakes), $0.24 \mathrm{Mg}$ of PM2.5 (about $37 \%$ from the abrasion of tire and brakes) and $2.2 \mathrm{~g}$ of benzo(a)pyrene and $0.21 \mathrm{Mg}$ of NMVOCs. Since 2015, when the bus fleet operated by the company Mobilis more than doubled, the amount of emissions of nitrogen oxides decreased by over $85 \%$ and of the dust from the combustion of fuel - by more than $77 \%$. Taking into account the emissions of pollutants such as particulate matter PM10 and PM2.5 from abrasion of tires and brakes, and benzo(a)pyrene in the analysed period, there was an increase in the total emissions of the new fleet by approximately 30,118 and $111.5 \%$ (more than twice). However, analysing these values for the equinumerous fleet in the years 2010-2014 and in 2015, a reduction in the emissions of pollutants can be noted - for PM10 
a)

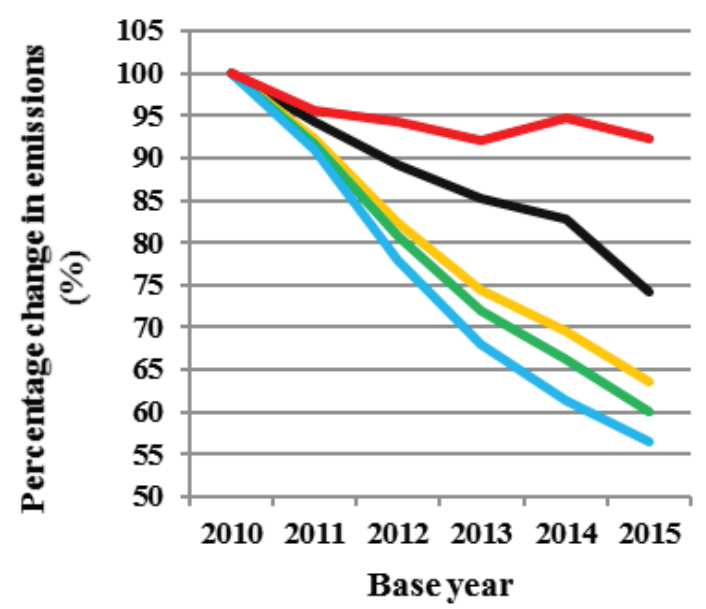

b) Mobilis group Sp. z o. o.

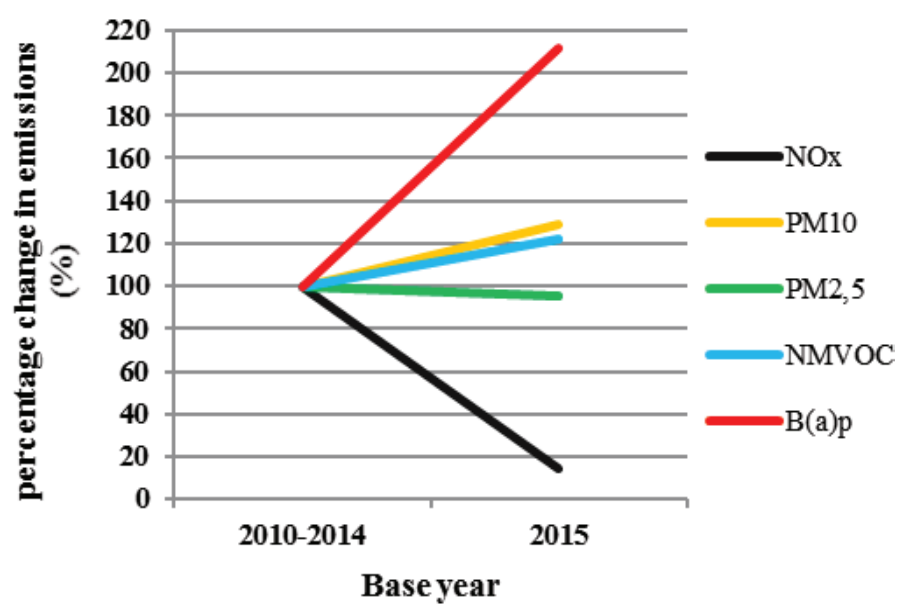

Figure 2. Variability in the absolute value of emissions of pollutants released into the air by the urban buses of MPK S.A. (a) and Mobilis group (b) in the years 2010-2015.

and PM2.5 from tire and brake abrasion by about $6 \%$ for each pollutant (a result of changes in the structure of exploited buses, i.e., different vehicle sizes such as midi, standard and articulated, mass of the buses, number of axle and load of the buses), and for benzo(a)pyrene by about $9 \%$. The situation is similar with respect to the non-methane volatile organic compounds (NMVOCs), where the total emission of the new fleets of 67 buses increased by over $22 \%$, compared to the period of 2010-2014 (29 buses), however, while adjusting this value to an equinumerous fleet, it is evident that NMVOCs emission was reduced by about $47 \%$. In both analysed calculation periods (2010-2014 and 2015), despite almost double the number of buses, there is a reduction in the total emissions of PM2.5 by nearly $4.5 \%$.

\section{SUMMARY AND CONCLUSIONS}

The evaluation of pollutants emitted into the air in the years 2010-2015 by the buses of MPK S.A. and the company Mobilis, carried out using the software COPERT 4 , demonstrated a positive effect of the modernization of the bus fleet on the amount of pollutants emitted into the air. The investments made by the Krakow carriers in the analysed period resulted in the number of fleet buses increasing from 543 vehicles in 2010 (83\% were the buses with engines which met the Euro I - Euro IV emission standards) to 576 vehicles in 2015 (about $50 \%$ of which were the buses which met the Euro V, EEV and Euro VI emissions standards). The modernization of the fleet significantly reduced the amount of dust-gas pollutants emitted into the air. Over these six years, the total nitrogen oxide emissions from the fleet of urban buses were reduced by over $28 \%$, of PM10 by nearly
$35 \%$, of PM2.5 by about $39 \%$, of NMVOCs by nearly $43 \%$. In the case of benzo(a)pyrene, the change in the absolute value of annual emissions in the analysed years was largely determined by the increasing number of fleet vehicles, with an unchanged value of the emission factor for this pollutant. However, it is necessary to take action, for example adequate transport policy to reduce traffic private transport in the agglomeration such as Krakow because the modernization of public transport will reduce emission of pollutants into the air, but does not solve the problem of its poor quality. Currently (as per our own unpublished researches), its share in the total volume of emission from the transport sector in that region is about $2.2 \%$ (since 2010, it was reduced by about $0.14 \%$ ). Over the six analysed years, the modernization of Krakow's bus fleet contributed to the reduction of $\mathrm{NO}_{x}$ emissions from the road transport sector by more than 1.5 $\%$ and nearly $1.3 \%$ of the total emissions of particulate matter (PM2.5, PM10, PMex). These changes show that if low-carbon or zero-emission urban buses transport are given priority in Krakow agglomeration, it will result in an improvement in air quality.

\section{ACKNOWLEDGEMENT}

The authors would like to extend their thanks to the company MPK S.A. in Krakow and the company Mobilis group Sp. $z$ o. o. in Krakow for providing the data, as well as to Mrs Ewelina Bączek, MSc for her valuable assistance in the performance of this research study. This study was supported by the AGH University of Science and Technology statutory research No.11.11.150.008 (Faculty of Mining Surveying and Environmental Engineering). 


\section{REFERENCES}

Ahanchian M., Biona J. B. M. 2014. Energy demand, emissions forecasts and mitigation strategies modeled over a mediumrange horizon: The case of the land transportation sector in Metro Manila. Energy Policy 66: 615-629. https://doi. org/10.1016/j.enpol.2013.11.026

Dulal H. B., Brodnig G., Onoriose C. G. 2011. Climate change mitigation in the transport sector through urban planning: A review. Habitat International 35, 3: 494-500. https://doi. org/10.1016/j.habitatint.2011.02.001

EMEP/EEA. 2013. EMEP/EEA air pollutant emission inventory guidebook 2013: Technical guidance to prepare national emission inventories. EEA Technical Report (12/2013) 23. https://doi.org/10.2800/92722

EMEP/EEA. 2016. EMEP/EEA air pollutant emission inventory guidebook 2016: Technical guidance to prepare national emission inventories. EEA Technical Report (09/30/2016). https://doi.org/10.2800/92722

European Parliament and Council of the European Union. 2009. REGULATION (EC) No 595/2009 OF THE EUROPEAN PARLIAMENT AND OF THE COUNCIL of 18 June 2009 on type-approval of motor vehicles and engines with respect to emissions from heavy duty vehicles (Euro VI) and on access to vehicle repair and maintenance information and amending Regulation (EC) No 715/2007 and Directive 2007/46/EC and repealing Directives 80/1269/EEC, 2005/55/EC and 2005/78/ EC. Official Journal of the European Union L188/1.

Gkatzofilias D., Kouridis Ch., Ntziachristos L., Samaras Z. 2012. COPERT 4. Computer programme to calculate emission from road transport. European Environment Agency, 5(February).

Grazi F. van den Bergh J. C. J. M. 2008. Spatial organization, transport, and climate change: Comparing instruments of spatial planning and policy. Ecological Economics 67, 4: 630639. https://doi.org/10.1016/j.ecolecon.2008.01.014

Hausberger S., Rexeis M., Zallinger M., Luz R. 2009. Emission Factors from the Model PHEM for the HBEFA Version 3. University of Technology, Graz, Report Nr. I-20/2009 HausEm. 33(I), 679. Retrieved from http://scholar.google.com/sch olar?hl=en\&btnG=Search\&q=intitle:Emission+Factors+from+ the+Model+PHEM+for+the+HBEFA+Version+3\#1
Kouridis C., Samaras C., Hassel D., Mellios G., Mccrae I., Zierock K., Hausberger S. 2013. EMEP/EEA emission inventory guidebook 2013, Update July 2014, CORINAIR. Retrieved from http://www.eea.europa.eu/publications/emepeea-guidebook-2013/

Kumar Pathak S., Sood V., Singh Y., Channiwala S. A. 2016. Real world vehicle emissions: Their correlation with driving parameters. Transportation Research Part D: Transport and Environment, 44: 157-176. https://doi.org/10.1016/j. $\operatorname{trd}$.2016.02.001

Martínez-Jaramillo J. E., Arango-Aramburo S., Álvarez-Uribe K. C., Jaramillo-Álvarez P. 2017. Assessing the impacts of transport policies through energy system simulation: The case of the Medellin Metropolitan Area, Colombia. Energy Policy, 101(October 2016), 101-108. https://doi.org/10.1016/j. enpol.2016.11.026

Mobilis group Sp. z o.o. 2016. Mobilis group Sp. z o.o. Retrieved from http://www.mobilis.pl/komunikacja-miejska/krakow.html

Moreno T., Rech, C., Rivas,I., Cruz-Minguillón M., Martins V., Vargas,C., Gibbons W. 2015. Urban air quality comparison for bus, tram, subway and pedestrian commutes in Barcelona. Environmental Research 142: 495-510. https://doi. org/10.1016/j.envres.2015.07.022

MPK S.A. 2016. Miejskie Przedsiębiorstwo Komunikacyjne w Krakowie. Retrieved from http://www.mpk.krakow.pl/

Nanaki E. A., Koroneo, C. J., Rose J., Susca T., Christensen T. H., Hurtado S. D. G., López-Jiménez P. A. 2017. Environmental Assessment of 9 European Public Bus Transportation Systems. Sustainable Cities and Society, 28: 42-52. https:// doi.org/http://dx.doi.org/10.1016/j.scs.2016.08.025

Rexeis M., Hausberger S., Kühlwein J., Luz R. 2013. Update of Emission Factors for EURO 5 and EURO 6 vehicles for the HBEFA Version 3. 2. University of Technology, Graz, Report Nr. I-31/2013 Rex-EM-I, 43(316). https://doi.org/Report No. I-25/2013/ Rex EM-I 2011/20 679

WIOŚ. 2017. Wojewódzki Inspektorat Ochrony Środowiska w Krakowie. Retrieved from http://www.krakow.pios.gov.pl/ 